\title{
DEVELOPMENT OF PLASTIC DEFORMATION \\ IN TWO-DIMENSIONAL COPPER POLYCRYSTALS WITH DIFFERENT TWIN STRUCTURE
}

\author{
Ye.V. Ftomov, E.E. Badiyan, A.G. Tonkopryad, O.V. Shekhovtsov, R.V. Shurinov \\ V.N. Karazin Kharkiv National University, Kharkiv, Ukraine \\ E-mail: Evgeny.E.Badiyan@univer.kharkov.ua
}

\begin{abstract}
Experimental studies of regularities of occurrence and development of substructural and orientational heterogeneity of polycrystalline copper foils with different twin structure in the process of their deformation in conditions of active tension have been carried out. It is shown that by selecting the regime of thermal treatment of fine-grained copper foil three types of samples with different twin structure can be obtained. The first type is characterized by the presence of twins, which differ in size, shape and type of boundaries. Samples of the second type contain twins with faceted boundaries. Samples of the third type contain parallel twins with rectilinear boundaries. Such a variety of twin structures not only predetermines the difference of mechanical characteristics for samples of different types but also regularities of substructure and orientation changes accompanying the plastic deformation of samples. The use of a highly sensitive imaging method that allows in situ characterization of substructural and orientational heterogeneity during deformation and other methods (optical and raster microscopy, interferometry) allowed us to detect specific features of the course of relaxation processes in samples of different
\end{abstract} types.

PACS: 61.82.Bg, 62.20.F-, 61.72.Lk

\section{INTRODUCTION}

There are several ways to create materials with different structures that can simultaneously exhibit high values of both strength and ductility. One of them is the creation of annealing twins in the structure of samples [1]. It is known that materials with low packing defect energy after annealing contain twins. Crystallographic parameters of annealing twin boundaries in metals with FCC structure were studied in detail in [2, 3]. It is established that the basic part of annealing twins in copper has low-energy special disorientation $\Sigma 3$. According to [4], the annealing bounds of such twins during plastic deformation may be both barriers for dislocation sliding and sources of dislocations. Thus, the role of annealing twins and their boundaries in the development of plastic deformation of materials is ambiguous.

\section{OBJECT OF THE STUDY AND METHODOLOGY OF THE EXPERIMENT}

Samples for studies with dimensions of $70 \times 10 \mathrm{~mm}$ were cut from copper foil $(99.95 \%)$ with different thickness of 100 and $400 \mu \mathrm{m}$, the initial average grain size of which was $0.01 \mathrm{~mm}$. The two dimensional polycrystalline samples (with one grain across thickness) with twin structures of three types were obtained by selecting the regime of thermomechanical treatment consisting of a preliminary annealing at $T=700{ }^{\circ} \mathrm{C}$ for two hours, deformation under conditions of uniaxial tension $3 \ldots 5 \%$ and recrystallization annealing at $\mathrm{T}=950{ }^{\circ} \mathrm{C}$ for three or six hours (Fig. 1). The samples were annealed in vacuum at residual pressure of $10^{-2} \mathrm{~Pa}$.

The first type of samples is characterized by the presence of twins, which are placed and oriented randomly in the grains. The length of twins was $2 \ldots 12 \mathrm{~mm}$, width $0.1 \ldots 1 \mathrm{~mm}$. Such twin structure was obtained in samples of copper with thickness of $400 \mu \mathrm{m}$ (see Fig. 1, type I). The second type of $100 \mu \mathrm{m}$ thick specimens contained twins with faceted boundaries (see Fig. 1, type II). The third type of $100 \mu \mathrm{m}$ thick specimens contained only parallel twins with rectilinear boundaries that crossed the entire surface of the specimen (see Fig. 1, type III).
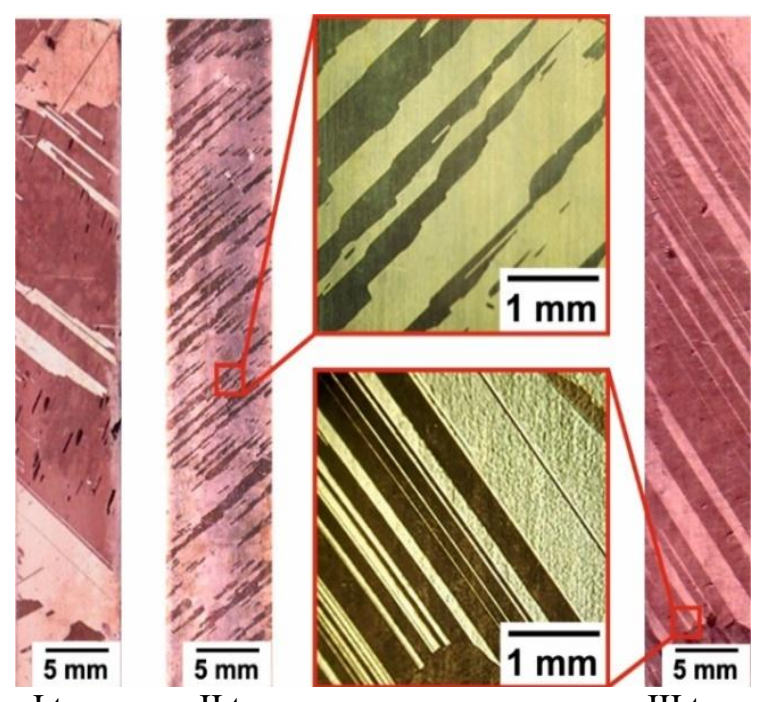

II type

III type

Fig. 1. Micrographs of the surface of two-dimensional $\mathrm{Cu}$ polycrystals with twins located and oriented randomly in the grains (I type), twins with facetted boundaries (II type), and parallel twins with rectilinear boundaries (III type)

The samples were deformed under conditions of active uniaxial tension with constant strain rate $\dot{\varepsilon}=5 \cdot 10^{-5} \mathrm{~s}^{-1}$ at room temperature. In the process of deformation, a strain curve in "stress-strain" coordinates and color orientation maps were automatically recorded using a PC [5-8]. Color orientation maps obtained in 
situ characterize structural, substructural, and orientation changes in any region of the sample that accompany plastic deformation. The microstructures of samples before and after deformation were further investigated using optical microscopy (MIM-8), interferometry (MIM-4) and scanning electron microscopy (TESKAN VEGA 3).

\section{INVESTIGATION OF PATTERNS OF PLASTIC DEFORMATION DEVELOPMENT IN COPPER FOIL SAMPLES WITH} ANNEALING TWINS

Fig. 2 shows typical strain curves for twodimensional polycrystalline $\mathrm{Cu}$ foil specimens of 400 and $100 \mu \mathrm{m}$ thickness whose structure contains randomly arranged twins and ordered twins with rectilinear or faceted twin boundaries.

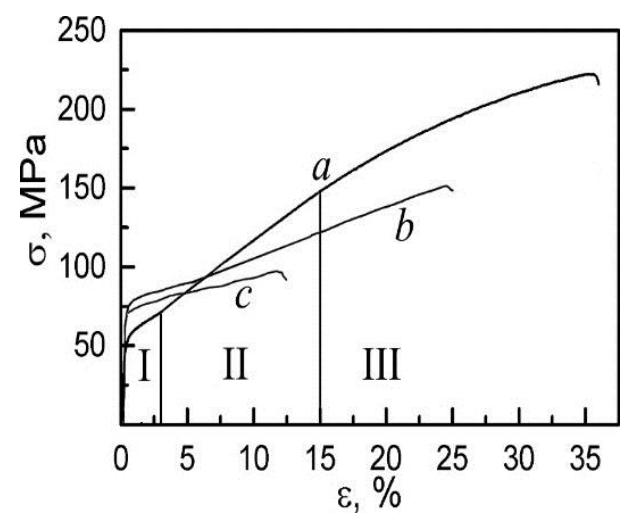

Fig. 2. Deformation curves for samples of $\mathrm{Cu}$ foils:

$a$-thickness of $400 \mu \mathrm{m}$, the twins are placed and oriented arbitrarily in the grains; $b$-thickness $100 \mu \mathrm{m}$, twins with faceted boundaries; c -thickness of $100 \mu \mathrm{m}$, parallel twins with rectilinear boundaries

It can be seen from Fig. 2, curve $a$ that $400 \mu \mathrm{m}-$ thick copper samples with arbitrarily arranged twins are characterized by relatively high ductility and high strength. Three stages can be distinguished in the strain curve for such samples (see Fig. 2, curve $a$ ): Itransitional stage, which follows the elastic region; II extended stage with linear dependence $\sigma(\varepsilon)$; III - stage (up to failure), which is characterized by close to parabolic dependence $\sigma(\varepsilon)$. The nature of substructural changes accompanying plastic deformation in the sample at different stages of plastic deformation is common for such samples. Analysis of the obtained in situ color orientation maps using their visualization method [7] shows that each stage of the deformation curve at the meso- and macroscopic level is characterized by a certain distribution of sub-grains in size and conditional crystallographic orientation. Some fragments of color orientation maps, the results of their visualization and the distribution of sub-grains in size and conditional crystallographic orientation for one of the grains of a $400 \mu \mathrm{m}$ thick $\mathrm{Cu}$ sample are shown below (Fig. 3). It can be seen that a particular substructure is characteristic of each stage of plastic deformation. This confirms the physical nature of stage deformation curves [9].
Fig. 2 (curves $b$ and $c$ ) show strain curves for $\mathrm{Cu}$ foil samples of $100 \mu \mathrm{m}$ thickness, which contain annealing twins with faceted and rectilinear boundaries, respectively. It can be seen from the figure that the second stage with linear dependence $\sigma(\varepsilon)$ with relatively low strain-hardening coefficient is observed on the strain curves after the transition stage. A similar character of $\sigma(\varepsilon)$ dependence is observed for the light sliding stage in monocrystals with FCC lattice.

Table shows the values of mechanical characteristics of different types of specimens: yield strength $\left(\sigma_{0,2}\right)$, tensile strength $\left(\sigma_{\mathrm{c}}\right)$ and maximum deformation of specimens before failure $\left(\varepsilon_{\max }\right)$. The reason for their noticeable difference, apparently, should be sought in the peculiarities of twin placement in the sample and the shape of their boundaries, as well as in the differences in the thickness of the samples.

Mechanical characteristics of the investigated $\mathrm{Cu}$ samples

\begin{tabular}{|c|c|c|c|}
\hline $\begin{array}{c}\text { Type of } \\
\text { samples }\end{array}$ & $\begin{array}{c}\sigma_{0.2}, \\
\mathrm{MPa}\end{array}$ & $\begin{array}{c}\sigma_{\mathrm{c}}, \\
\mathrm{MPa}\end{array}$ & $\varepsilon_{\max }, \%$ \\
\hline Type I & 48 & 225 & 35 \\
\hline Type II & 66 & 130 & 25 \\
\hline Type III & 60 & 80 & 14 \\
\hline
\end{tabular}

STRUCTURAL AND SUBSTRUCTURAL CHANGES IN COPPER SAMPLES DURING PLASTIC DEFORMATION DEVELOPMENT

The twinned structure and the placement of twins in the sample predetermine the nature of the onset and development of dislocation slip, structural and substructural changes. Thus, in type III $\mathrm{Cu}$ samples containing parallel twins with rectilinear boundaries a single slip occurs. Its development continues up to the specimen failure (Fig. 4). It should be noted that the slip direction is the same for all twins. This testifies to the same crystallographic orientation of all twins relative to the tensile axis.

In some grains of investigated $\mathrm{Cu}$ specimens of the first type, already at early stages of plastic deformation, multiple sliding occurs (Fig. 5), which, as a rule, leads to occurrence and development of a rotational mode of plastic deformation. It is manifested on the specimen surface in the form of reorientation bands of different types (Fig. 6). The change in shape of twins of different types in grain body of first type copper specimens in the deformation process does not occur, as a rule (Fig. 7).

Using high-resolution techniques [5-8] to determine in situ substructural and orientation changes in any part of the sample surface during their deformation, a change in the crystallographic orientation of twins and the effect of disappearance of interfaces at a certain degree of deformation were found in $\mathrm{Cu}$ type 1 specimens. Fragments of color orientation maps, which illustrate this effect rather well, are shown in Fig. 8. It can be seen from Fig. 8 that a change in twin orientation in the strain range from 0 to $7 \%$ leads to the disappearance of the boundaries between the grain body and the twin. With increasing strain, further reorientation of the twins occurs. 
State I $(\varepsilon=0 \ldots 3 \%)$

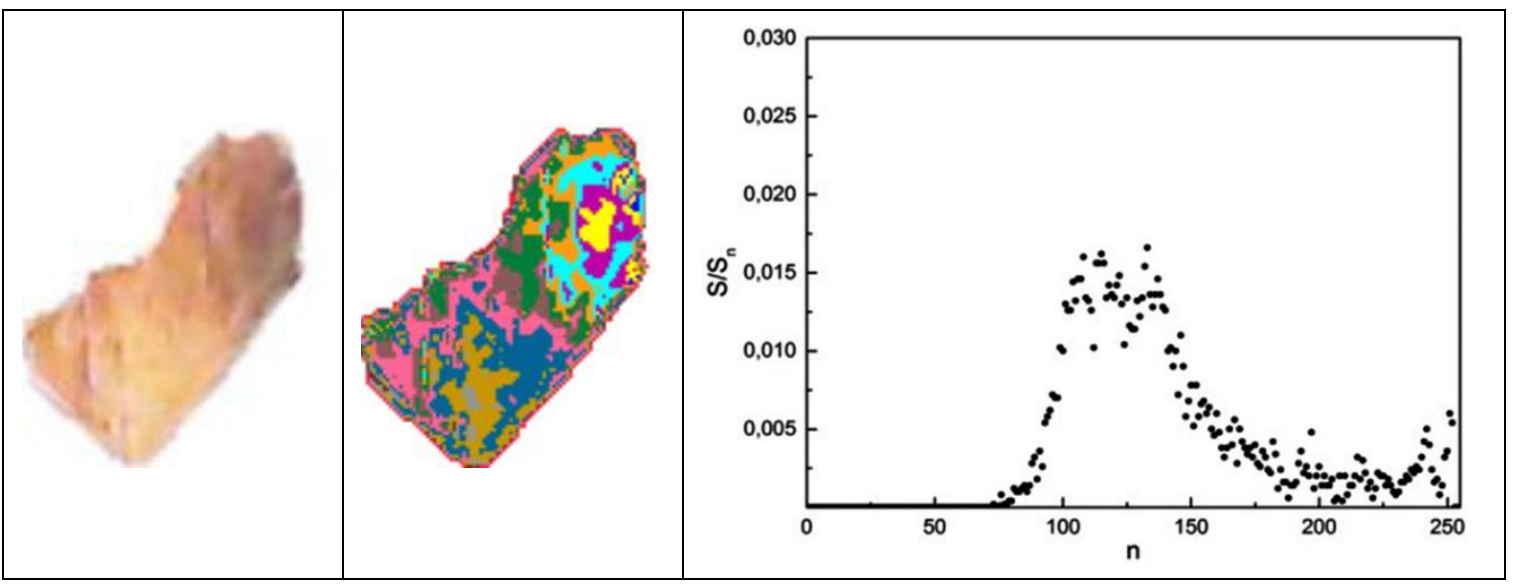

State II $(\varepsilon=3 \ldots 15 \%)$

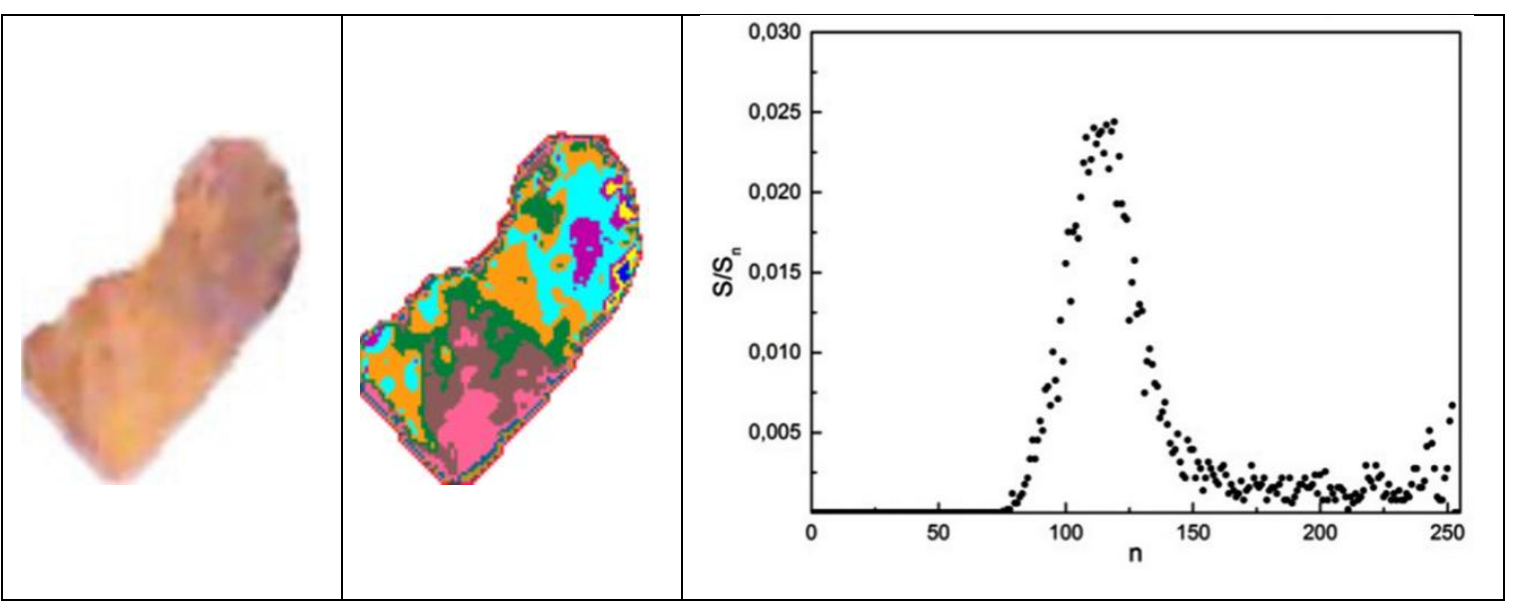

State III $(\varepsilon=15 \ldots 35 \%)$

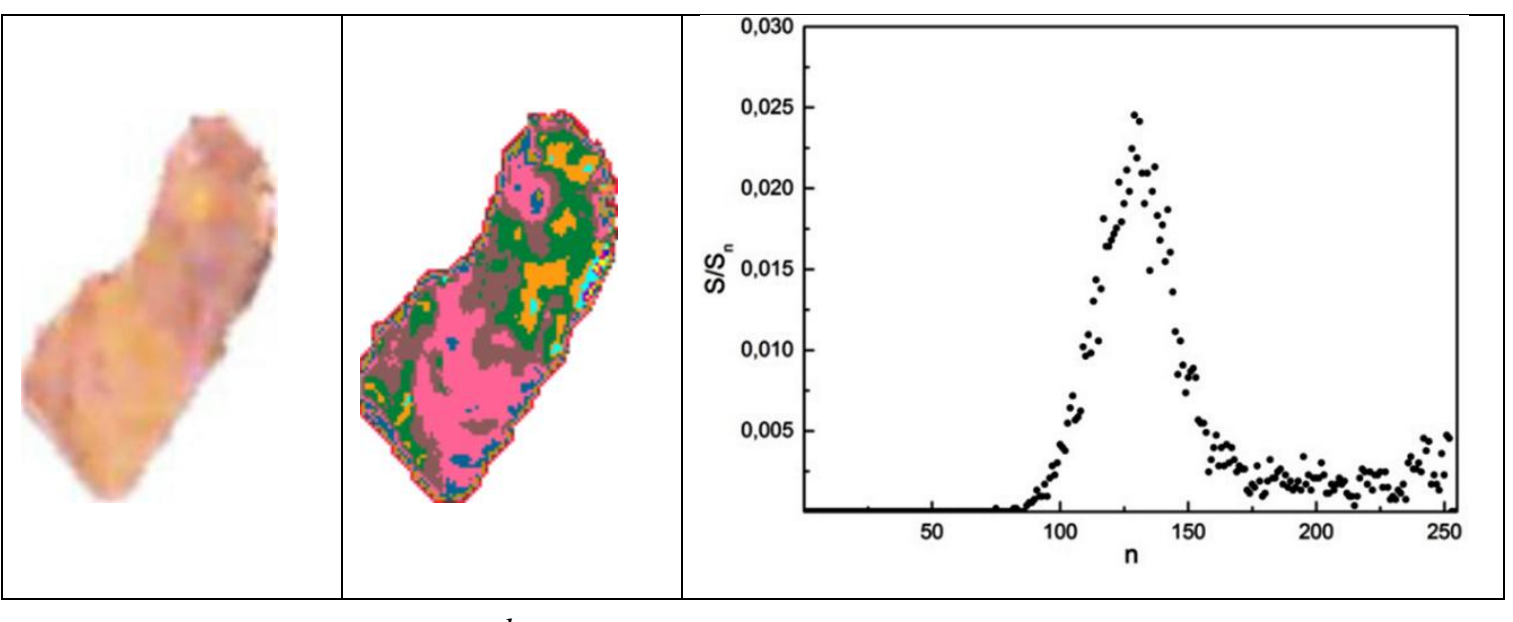

$a$

Fig. 3. Color orientation maps (a), results of their visualization (b) and distribution of subgrains in size and conditional crystallographic orientation (c) for one of the grains of a $400 \mu \mathrm{m}$ thick $\mathrm{Cu}$ sample for different stages of sample deformation 


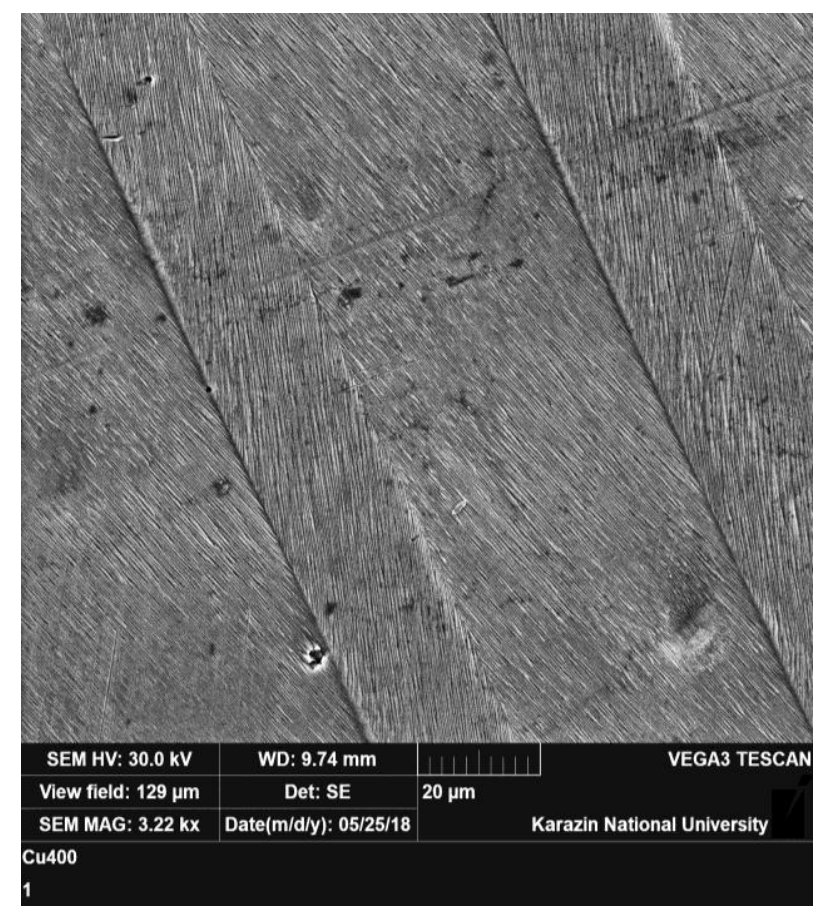

Fig. 4. Fragment of the surface of the deformed sample $\mathrm{Cu}$ (III type), illustrating a single slip in twins with parallel boundaries $(\varepsilon=14 \%)$

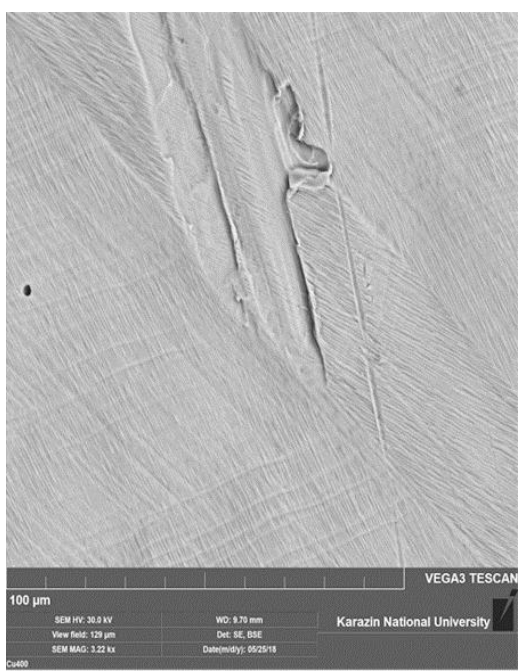

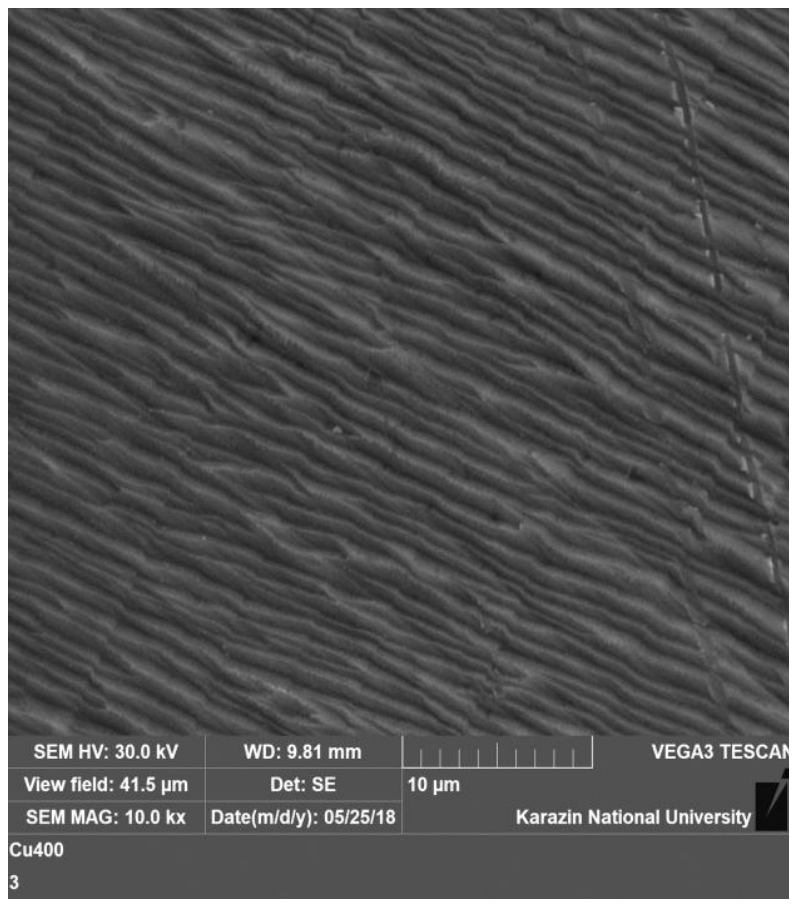

Fig. 5. Surface fragment of a deformed Cu sample (type I) illustrating multiple sliding in one of the grains $(\varepsilon=22 \%)$

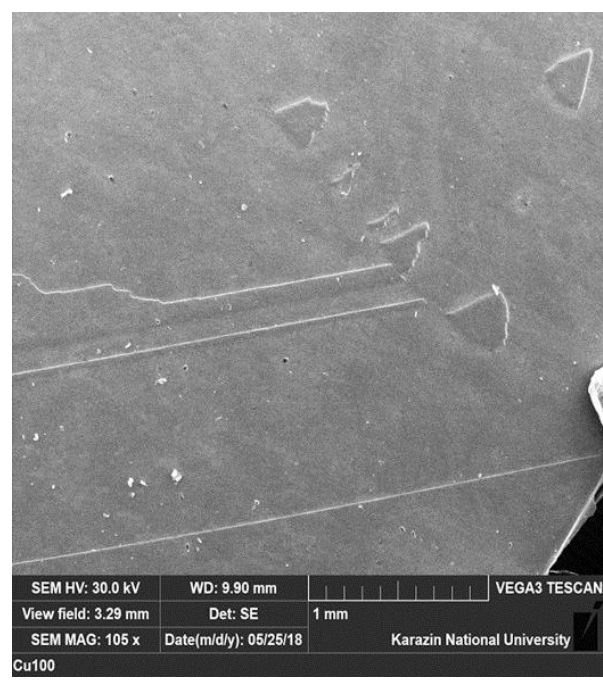

$b$

Fig. 6. Examples of reorientation bands of different types in the structure of deformed Cu samples of the first type $(\varepsilon=22 \%)$
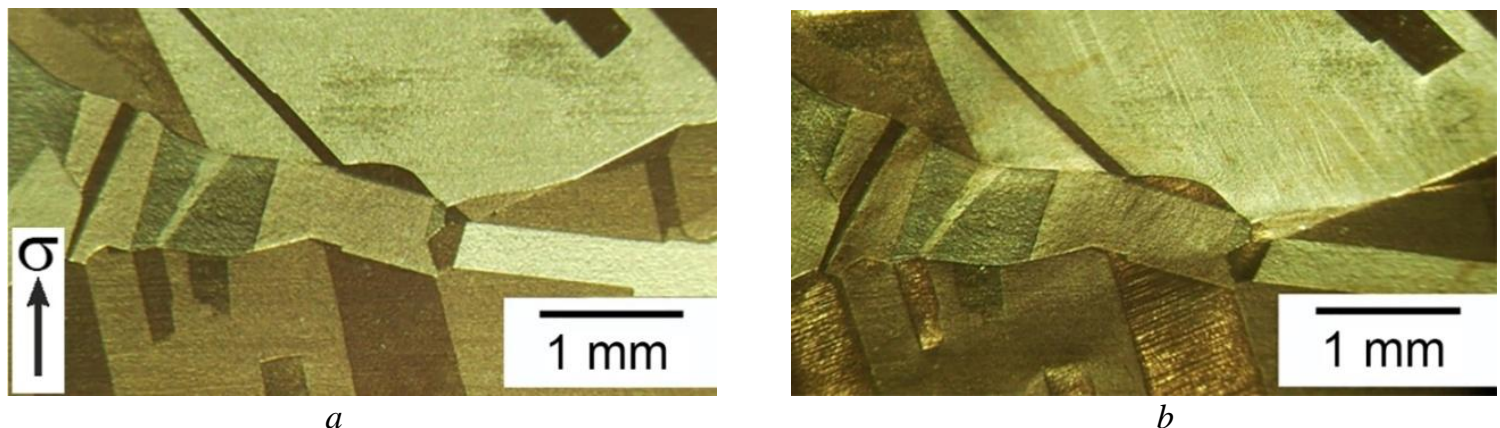

Fig. 7. Microphotographs of the surface fragment of the first type Cu sample before (a) and after (b) deformation $(\varepsilon=16 \%)$ 


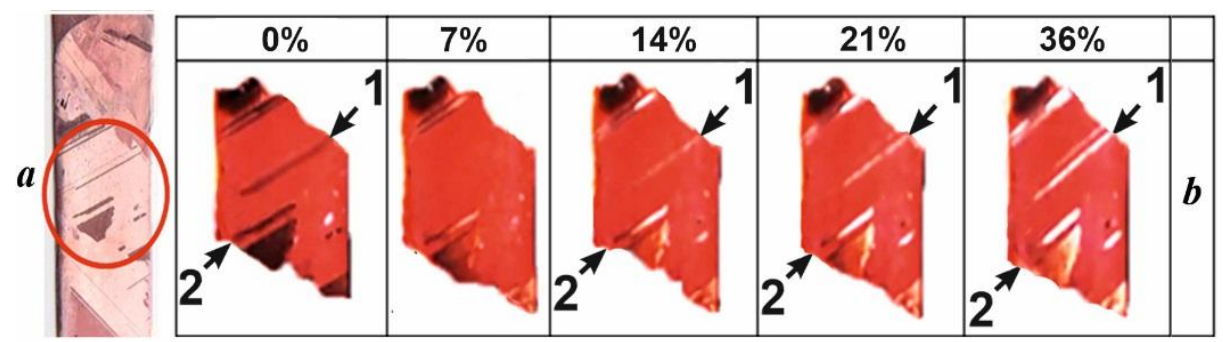

Fig. 8. Microphotograph of the surface area of the first type Cu sample (a) and fragments of the color orientation maps for this area obtained in situ during deformation of the sample to $\varepsilon=36 \%(b)$

The image of the twin on the color orientation map gradually changes color. This means that the crystallographic orientation of the twin after deformation differs from the initial one. A similar effect takes place for other twins (e.g., twin 2 in the same grain).

In $\mathrm{Cu}$ samples with facetted twin boundaries (type II) a deformation relief is formed in the twin region during deformation (Fig. 9). It represents chaotically placed in a body of twins microfragments with different

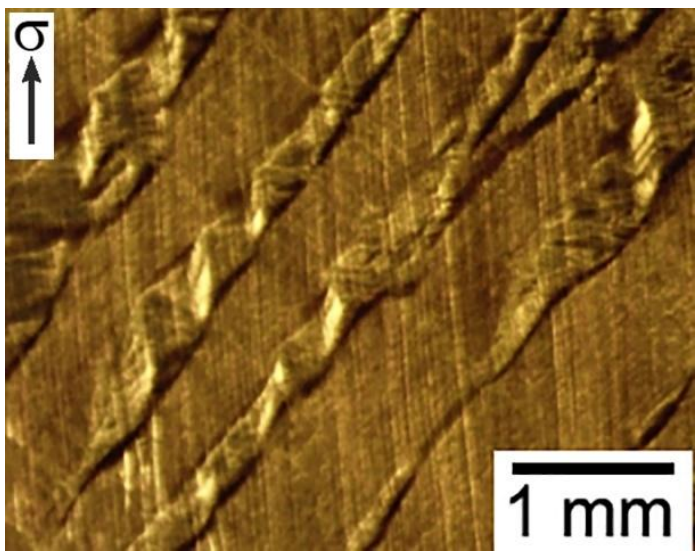

$a$ crystallographic orientation. The presence of this relief on the surface of deformed samples is confirmed by studies of the surface structure using a raster microscope (Fig. 10) and the results of interferometric studies (Fig. 11). The interference pattern obtained from the twin surface with faceted boundaries (see Fig. 11,b) indicates the irregularities of this surface. The linear dimensions of the irregularities are difficult to estimate, since the curvatures of the interference lines are too large.

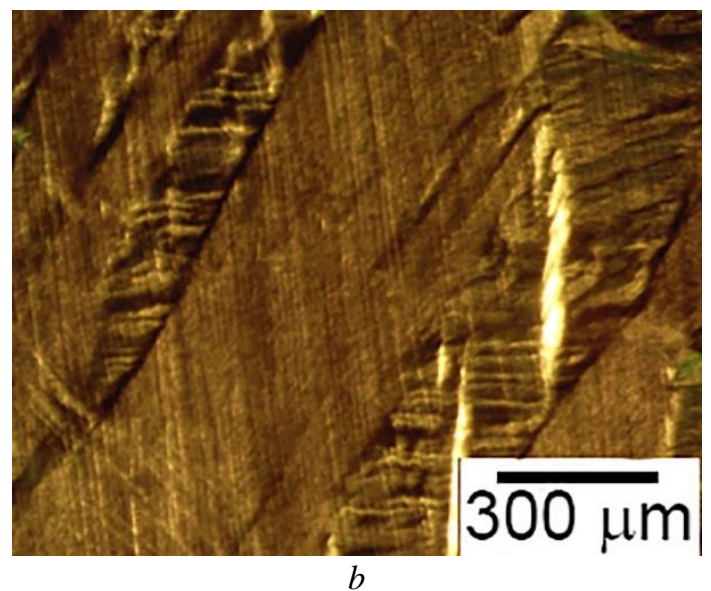

Fig. 9. Microphotographs of surface fragments of Cu (type II) sample with faceted twin boundaries after deformation $(\varepsilon=25 \%)$

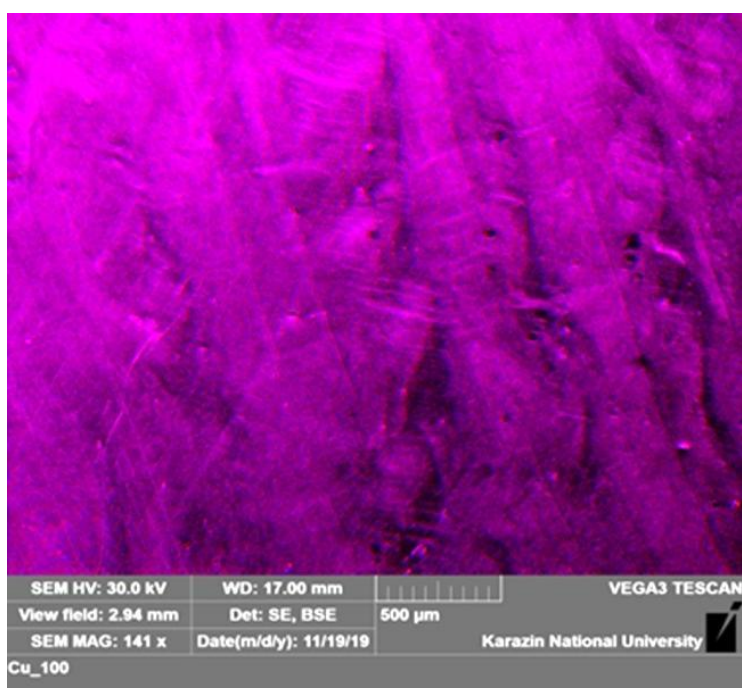

Fig. 10. Microphotograph of $\mathrm{Cu}$ (type II) sample surface fragment with faceted twin boundaries after deformation $(\varepsilon=25 \%)$ 

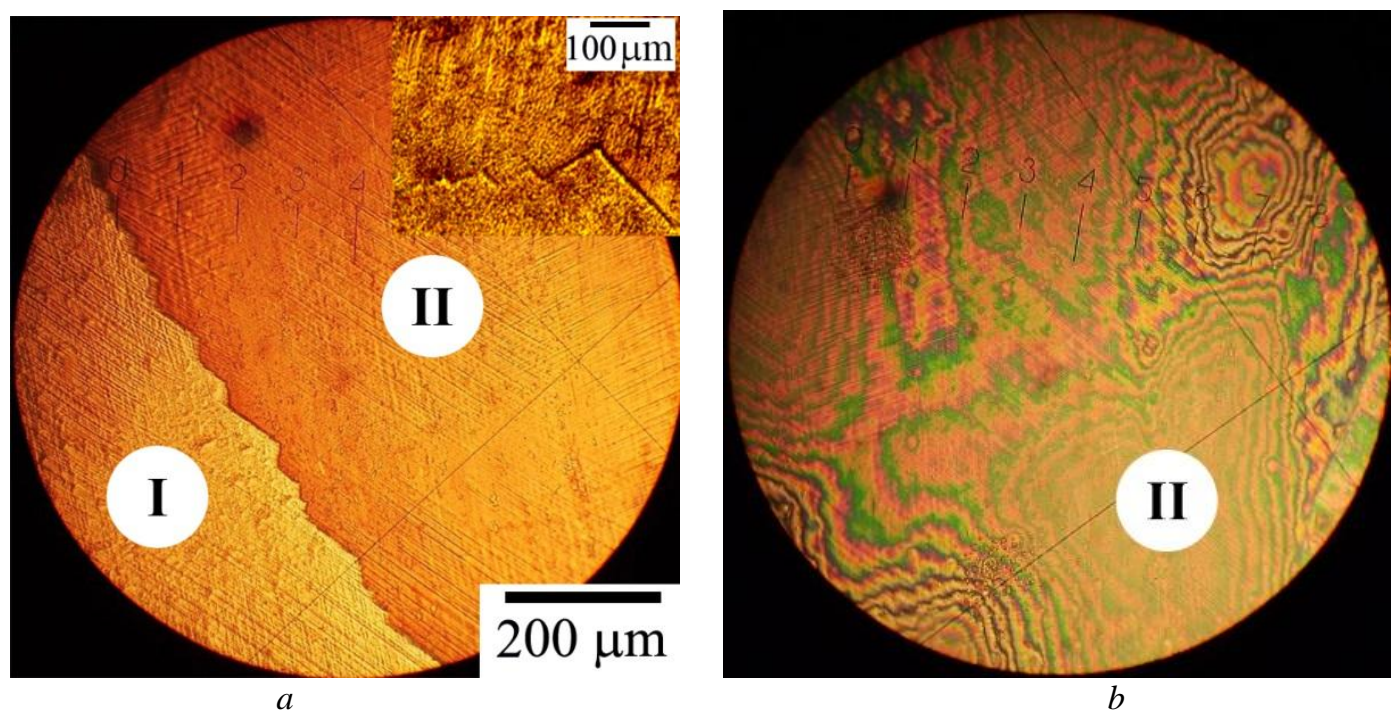

Fig. 11. Microphotograph of a surface fragment of a $20 \%$ deformed Cu (II type) sample at the boundary "sample body (I) -faceted twin (II)" (a) and the interference pattern obtained from the twin surface (II) (b)

The color orientation maps obtained from the surface of doubles with faceted boundaries in situ during deformation of type II $\mathrm{Cu}$ samples show that already at the initial stage of deformation of the sample in doubles with faceted boundaries the reorientation of individual fragments in the body of the doubles is observed. This process continues until the specimen fractures (Fig. 12).

In the deformation process, shear processes also develop due to dislocation sliding. It can be assumed that plastic deformation in such $\mathrm{Cu}$ samples occurs by a self-consistent combination of shear and unfolding of individual structural elements of the deformation volume. Apparently, these processes occur due to the fact that numerous short facets of boundaries are active sources of dislocations, as indicated by the results of [4, 11]. The authors of [4, 11] show that dislocations emitted by twin boundaries on short facets necessarily cause curvatures in the crystal lattice. This curvature manifests itself by creating disorientation at the graintwin boundary. It can be assumed that such relaxation processes at the mesolevel are carried out according to the "shear + rotation" scheme. In the process of sample deformation these processes are activated (see Fig. 12).

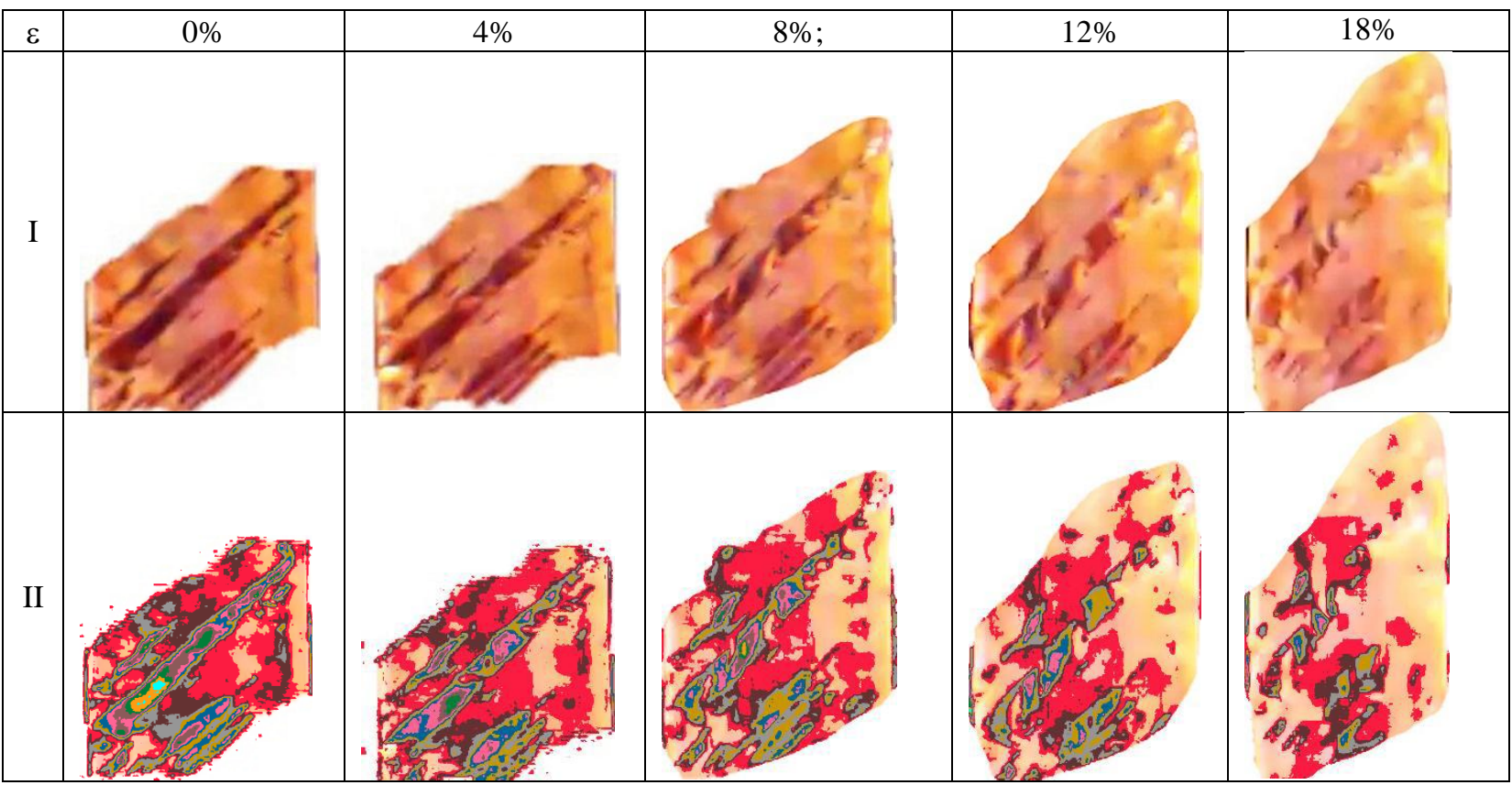

Fig. 12. Color orientation maps (I) for the surface of a sample fragment with twin faceted boundaries obtained in situ during deformation of the sample and the same fragments after visualization (II) of orientation changes in the grain

It should be noted that such substructural changes are observed only in $100 \mu \mathrm{m}$ thick copper samples that contain annealing twins with faceted boundaries in their structure. 


\section{CONCLUSIONS}

It is experimentally shown that from fine-grained copper foils by selection of a regime of thermomechanical processing and thickness of a sample it is possible to receive various twin structure. It differs in the size of twins, their placement and orientation in a sample (I type), a form of twins and a way of their placement in a sample and type of twin boundaries: twins with faceted borders (II type), parallel twins with rectilinear borders (III type).

Relaxation mechanism of stress state during plastic deformation of copper samples with high content of twins located randomly in the sample was revealed: twins reorientation in the process of plastic deformation occurs with their shape preservation. It was found that twins with parallel boundaries which occur in one grain have identical crystallographic orientation. During deformation of samples shear processes on twin boundaries, migration of twin boundaries and possible twin merging were not observed.

In $100 \mu \mathrm{m}$-thick copper samples, the relaxation processes that can be characterized as "shear + rotation" in mesoscopic deformation volumes are actively developing in annealed twins with faceted boundaries.

\section{REFERENCES}

1. Y.E. Shen, L. Lu, Q.H. Lu, Z.H. Jin, K.Lu. Tensile properties of copper with nano-scale twins // Scripta Materialia. 2005, v. 52, p. 989-994.

2. Ч.В. Копецкий, В.Ю. Новиков, Л.К. Фионова, Н.А. Большакова. Кристаллография двойников отжига в металлах с ГЦК-структурой // Доклады Академии наук СССР. 1984, т. 274, №5, с. 1099-1102.

3. J. Gilman. Dislocation Dynamics and the Response of Materials // Journal Applied Mechanics Reviews. 1968, v. 21, N 8, p. 767-783.

4. K. Konopka, J.W. Wyrzykowski. The effect of the twin boundaries on the yield stress of a material //
Journal of Materials Processing Technology. 1997, v. 64 , p. $223-230$.

5. Пат. 89743 Україна: МПК G01B 11/16. № а 2009 06455. Спосіб контролю орієнтаційних змін у кристалічних матеріалах «in situ» в процесі зовнішнього впливу. Заявл. 22.06.09; опубл. 25.02.10. Бюл. №4.

6. Пат. 93021 Україна: МПК G01N 21/00, G01N 21/17, G01N 33/20. № a 2010 02923. Спосіб визначення кристалографічної орієнтації зерен на поверхні полікристалічного зразка. Заявл. 15.03.10; опубл. 27.12.10. Бюл. №24.

7. Пат. 104249 Україна: МПК G01N 21/00, G01N 33/20. № a 2012 14845. Спосіб візуалізації орієнтаційної неоднорідності та морфології поверхні монокристала або окремих зерен полікристала. Заявл. 24.12.12; опубл. 10.01.14. Бюл. №1.

8. E.E. Badiyan, A.G. Tonkopryad, O.V. Shehovtsov, R.V. Shorinov, T.R. Zetova. Optical Technique for the in Situ Study of Orientation and Structure Changes Accompanied the Plastic Deformation of Polycrystalline Specimens of Aluminum // Inorganic Materials. 2011, N 15, p. 16631666.

9. Н.А. Конева, Э.В. Козлов. Физическая природа стадий пластической деформации // Физика. 1990, т. 33, №2, с. 89-106.

10. D.P. Field, B.W. True, T.M. Lillo, J.E. Flinn. Observation of twin boundary migration in copper during deformation // Materials Science and Engineering A. 2004, v. 372, p. 173-179.

11. О.Б. Перевалова, Н.А. Конева, Э.В. Козлов. Роль границ разного типа в накоплении кривизныкручения кристаллической решетки при деформации поликристаллического сплава $\mathrm{Ni}_{3} \mathrm{Fe}$ в состоянии с дальним атомным порядком // Физика металлов $u$ металловедение. 2004, т. 98, №5, с. 78-84.

Article received 17.11.2021

\section{РАЗВИТИЕ ПЛАСТИЧЕСКОЙ ДЕФОРМАЦИИ В ДВУМЕРНЫХ ПОЛИКРИСТАЛЛАХ МЕДИ С РАЗЛИЧНОЙ ДВОЙНИКОВОЙ СТРУКТУРОЙ}

\section{Е.В. Фтёмов, Е.Е. Бадиян, А.Г. Тонкопряд, О.В. Шеховцов, Р.В. Шуринов}

Проведены экспериментальные исследования закономерностей возникновения и развития субструктурной и ориентационной неоднородностей поликристаллических фольг меди с различной двойниковой структурой в процессе их деформирования в условиях активного растяжения. Показано, что подбором режима термообработки мелкозернистой фольги меди можно получить образцы с различной двойниковой структурой трех типов. Для первого типа характерно наличие двойников, которые отличаются по размерам, форме и типу границ. Образцы второго типа содержат двойники с фасетчатыми границами. Образцы третьего типа содержат параллельные двойники с прямолинейными границами. Такое разнообразие двойниковой структуры предопределяет не только различие механических характеристик для образцов разного типа, но и закономерности субструктурных и ориентационных изменений, сопровождающих пластическую деформацию образцов. Использование в работе высокочувствительного метода визуализации, позволяющего in situ в процессе деформации определять характеристики субструктурной и ориентационной неоднородностей, и других методов (оптической и растровой микроскопии, интерферометрии) позволило обнаружить особенности протекания релаксационных процессов в образцах различного типа. 


\section{РОЗВИТОК ПЛАСТИЧНОЇ ДЕФОРМАЦІЇ В ДВОМІРНИХ ПОЛІКРИСТАЛАХ МІДІ З РІЗНОЮ ДВІЙНИКОВОЮ СТРУКТУРОЮ}

\section{С.В. Фтьомов, С.Ю. Бадіян, А.Г. Тонкопряд, О.В. Шеховцов, Р.В. Шурінов}

Проведено експериментальні дослідження закономірностей виникнення та розвитку субструктурної та орієнтаційної неоднорідностей полікристалічних фольг міді з різною двійниковою структурою в процесі їхнього деформування в умовах активного розтягування. Показано, що підбором режиму термообробки дрібнозернистої фольги міді можна отримати зразки з двійниковою структурою трьох типів. Для першого типу характерна наявність двійників, які відрізняються за розмірами, формою та типом меж. Зразки другого типу містять двійники 3 фасеточними межами. Зразки третього типу містять паралельні двійники 3 прямолінійними межами. Така різноманітність двійникової структури зумовлює не тільки відмінність механічних характеристик для зразків різного типу, а й закономірності субструктурних та орієнтаційних змін, які супроводжують пластичну деформацію зразків. Використання в роботі високочутливого методу візуалізації, що дозволяє in situ в процесі деформації визначати характеристики субструктурної та орієнтаційної неоднорідностей, та інших методів (оптичної та растрової мікроскопії, інтерферометрії) дозволило виявити особливості протікання релаксаційних процесів у зразках різного типу. 